\title{
Civic Engagement, Political Development,and the Role of the Young Citizen
}

\author{
Syaifullah \\ Department of Civic Education, Faculty of Social Science Education \\ Universitas Pendidikan Indonesia \\ syaifulsyam@yahoo.com
}

\begin{abstract}
Citizen involvement in various activities of the society, nation and the state is a matter that cannot be negotiable. It is not the other, as in any self- citizens have rights and obligations attached, every citizen has the right and duty that must be carried out properly and full responsibility. The rights and duties have been guaranteed in the country's constitution or basic law. As we know, that one feature of a democracy or representative government is a constitutional guarantee of the rights and obligations of citizens. It is not the other, so that the rights and duties is respected or appreciated by every citizen. How important the protection of constitutional or constitutional guarantees of the rights and obligations of citizens, making every country take reasonable steps to authority or its authority, issued a wide variety of regulations or rules that must be enforced and implemented by all citizens, without exception. Citizen involvement in various activities with civic engagement is called, which is essentially a manifestation of the right and duty of every citizen.
\end{abstract}

Keyword: citizen, society, rights, duties, representative government, civic engagement

\section{INTRODUCTION}

There are five attributes of citizenship inherent in every citizen, namely (1) a sense of identity, (2) the enjoyment of certain rights, (3) the fulfillment of corresponding obligations, (4) a degree of interest and involvement in public affairs, and (5) an acceptance of basic societal values [1]. In the author's view, the fifth attribute is a unified whole (integral comprehensive that cannot be separated from one another. However, for the sake of assessment or analysis, it can be done partially.

In this article, will be elaborated on any of the attributes of the third attribute of the corresponding obligation fulfillment, in the sense of the obligation of citizens to perform the duties inherent (inherent) within each citizen. In this context, the author raised about one of the basic concepts (basic concept) in Citizenship Education (hereinafter abbreviated Civic education) the political participation of citizens as an integral part of the third attribute.

Political participation is one manifestation or embodiment of civic duties in the context of country life.
Political participation is actualized according to ability or capacity of every citizen, depending on its status or position. Political participation is a form of citizen participation more broadly (in large sense). Typically, participation is defined as involvement or participation of citizens in the various activities of the community, state and nation. In the context of Civic education, there is an important concept related to how the involvement of citizens in the various activities in the state and varous of activities.

\section{The NATURE OF CIVIC ENGAGEMENT}

Most certainly, there are a variety of definitions or understanding of Civic Engagement proposed by the expert or experts. In the editorial, is certainly understanding given will vary widely, depending on the angle of view (point of view) that is used by every expert who bring it. Therefore, no undisputed understanding about the difference formulation, we are able to find all the basic elements or the essential concept is defined. Here are a few sense of Civic Engagement referring to various sources or references that can be trusted.

Civic Engagement consists of two words namely civic and engagement. In effect in a variety of references, defined as a citizen or civic citizenship. While engagement is defined as " .... typically, engagement is understood as discipline - based work (a course assignment, a research project, an internship, fieldwork, a clinical placement and so on) that occur in non- academic community (local, national, global [2].

Meanwhile, the American Psychologist Association (2012) defines civic engagement as "Individual and collective actions designed to identify and address issues of public concern. "

Based on the above understanding, civic engagement is defined as the collective and individual actions undertaken to identify and demonstrate public interest issues. Referring to this definition. the concept of civic engagement (hereafter CE) has close links with the democratic government.

Another understanding of CE can be expressed by [3] " ... is about the right of the people to define the 
public good, Determine the policies by the which they will seek the good, and reform or replace institutions that do not serve that good. Based on this definition, it means that approximately Civic Engagement with regard to the rights of citizens to define the public interest, determining which policies they see the good things, and fix the institutions that will provide services to the public about the things that to be achieved. political knowledge is a Necessary precondition to civic engagement, but unlike in information per se to be a sufficient precondition to civic engagement [4]. Based on this statement, it is understood that there is a precondition for realizing the civic engagement and political knowledge is far more important is with regard to information.

So, in fact, to develop civic engagement is important that the necessary condition with respect to information and political knowledge. Therefore, political knowledge is a precondition for developing the civic engagement by political thinkers from Jefferson to Dewey assume that better education is the solution. furthermore, the long standing empirical observation that years of formal education are highly correlated with political knowledge seems to support this solution [4].

The opinion above, explicitly asserted that the role of education in developing civic engagement is very important and is the best solution, as expressed political thinkers, such as Jefferson and Dewey. If interpreted more widely, the actual concept of civic engagement is closely related to the citizen as a human being as a creature of political or social or friendly with always using a variety of influence that the other residents.

\section{Actualization of Civic ENGagement IN THE POLITICAL COMMUNITY.}

The scope of the term engagement, it is very broad because it deals with the activities of citizens in various levels of local, national, and global. Of course, civic engagement should be actualized in real life [2].

In other words, every citizen is required to actualize the dimensions of civic engagement in various aspects of life of the community, nation, and state. This demand is very rational, given the citizens a political creature. As Aristotle stated, that man is a zoon politicon, which means that humans by nature gregarious. Humans can live happily if he is in the country, and state life.

Often, the term "zoon politicon" was interpreted as political beings, which in turn is given meaning as the creatures that live in groups, in community groups, also in the state.

So, in general, means that human beings politics by nature is a living creature that cannot stand alone without help from others. He lived because in the midst of society, and in the communities in humans can develop all its human potential. Therefore, no one said that society as a container of human humanizing. The personal moral responsibility can only flourish within the framework of unity and dealing with the public [5].

So, based point of view, it is clear that society is an embodiment of human beings as political, because in humans is society can interact with each other to deliver a wide range of interests owned by each. The political dimension can be defined as the human dimension in which humans recognize themselves as members of the community, as a member of a whole which determines the framework of life and determined again by his behavior [5].

In the position as political beings, then a thing to be possessed man is awareness of the rights and obligations inherent in him. Rights intended as everything must be obtained or acquired by humans in life in society. While that is a liability is anything that should be implemented or accomplished by humans in life in the community to obtain all their rights. The relationship between the rights and obligations cannot be separated from each other. There are no rights without fulfilling the obligation, and no obligations without rights. [6], humans as political beings should have the attitude and actions that reflect " political literacy " (political literacy), which has several characteristics including: (1) know the laws and constitution of the country; (2) know the problem; (3) propose alternative solutions in accordance with its capabilities. Meanwhile, in the view of John Cogan and Derricott [1], characteristics that must be owned by nationals, includes the following: (1) The ability to look at and approach problems as a member of the global community; (2) Ability to work with others in a cooperative and responsible manner to the role and responsibilities in society; (3) The ability to understand, accept , and tolerance for cultural diversity; (4) The ability to think systematically and critically; (5) The willingness to resolve the conflict peacefully; (6) Desire to change lifestyle and consumer habits to protect the environment. (7) The ability of sensitive and defend human rights. and (8) The willingness and ability to participate in politics locally, nationally, and internationally.

What Cogan stated above, is a matter that must be observed and even applied by every citizen in realizing the inherent political character of man in man. Spranger, a social scientist, gives humans classified into six types of human. One of them is the type of human behavior is essentially political power. Spranger 's opinion, analyzing the concept of politics in the narrow sense of power. So naturally, when he said, basic human behavior is the type of political power or want power.

Similar opinion expressed by John Locke who recognize the natural properties of the human person who at any given moment will arise. The properties of which want power, want to be respected / appreciated, want to live forever. 
The idea of a political community or alliance of political life was first put forward by Aristotle in his famous Political. In the book he introduced the term politic koinonia, which means the communion of life in the form of policy. Thus according to Aristotle, the state is defined as a union of political life. There are several things important records of the political life of the communion statement, as described by Rapaar (1993) as follows:

1) With the alliance of political life, meant that the state is not just a mere instrument. State nor merely a collection of organizations that regularly or machine parts that make the machine called a machine, but a living communion which indicate the presence of an organic nature connectedness between citizens of one another.

2) The term koinonia (communion) in classical Greek suggests the existence of a special relationship between people, which is so close, very close, very intimate and sustainable.

3) For Aristotle, if the state is a political alliance that is as a living organism, and the existence of a special relationship between citizens, familiar, intimate and continuous sustainably maintained and cared for, then by itself will be able to realize the unity and integrity of the country that became the desire of all citizens state.

4) State political life as a community are in the highest level and most sovereign fellowship among the various forms of life that exist in society. Said to be the highest level and most sovereign, because it has a very noble goal and surpass the highest goal of life fellowships others.

Surbakti (1992) explore the characteristics of political society, with the start of the explanation of the concept " society " and " political ". According to him, politics is the process of making, implementation, and enforcement of decisions in the public interest. While historically, politically interpreted as an attempt to talk about what is the common good of the citizens who live in the policy. Following that according Surbakti, there are four characteristics of political society (political system of the nation - state ), namely :

1) Citizens state ( political society) organizations more than other sub-communities .

2) The scope of matters handled by the state society is much broader than the matters dealt with by the other sub-communities organization.

3) In general, the political society (the state) have the resources ( material and human) are much larger than other community organizations, so that country people have a greater ability to implement its policies.
4) Political society ( the state) has the power and authority, including the authority of the legitimate use of physical force that monopolized the country as well as experts and implementation ( bureaucracy) that is greater than that belongs to other community sub organizations.

Thus, in the political community characteristics as stated above, every citizen can actualize civic engagement or involvement itself in many aspects of community life, social, cultural, economic, and political. In container political society, every citizen is required to be able to actualize itself as the embodiment of his involvement as a human or a political creature.

\section{THE ROLE OF YOUNG PEOPLE IN THE DEVELOPMENT OF CIVIC ENGAGEMENT, RELATION TO POLITICAL DEVELOPMENT. .}

We know that one of the aims of Civic education is to prepare and realize the younger generation (young generation) that has an advantage in knowledge, attitudes, and skills of citizenship. With young citizens who have such a competence advantage, it will greatly promote the establishment of nation-building.

Political development (political development, as stated by Lucian W. Pye ( Kurniadi , 1987) has many conceptual understanding formulas, one of which he argued that " ... political development as the development of democracy and the stability and change of social order ". Referring to this notion, it is understood that political development has a very close relationship with the development of democracy and stability and social order.

Talking about political development, as well as fostering democracy and stability and social order, is closely related to the political system ever enacted or implemented within the Indonesian nation trip. But before understanding the political dynamics, it is important to first understand the meaning of the meaning or the political system really is.

Meanwhile, in view of Miriam Budiardjo (1989), the concept of a political system based on the study of political phenomena in the context of behavior in society. Political behavior is considered as part of the overall social behavior. The political system is one of the various systems contained in people's lives.

From the above, it can be concluded that the political system has inherent distinctiveness, which is the uniqueness of it to distinguish it from other systems that 
exist in society. Meanwhile, a political scientist named David Easton defines the political system as a set of interactions are abstracted from the totality of social behavior, through which the values propagated to a society. Based on this understanding, it is clear that the political system in respect of or include political life.

One component of the nation that plays a major role in the context of political development it is the younger generation. Should be limited in advance that in this context is the generation etymologically means descendants who have blood relations. While the social science, understanding the generation formulated as follows:

The period between birth parents and their children. All children of a father or a mother, a father or mother, although it covers a long period of time. Calculation of the historical time frame of approximately 30 years. Contemporary, anybody from the newborn to the oldest people living together at the same time. Kuval (Coeval), anyone who is the same age and grew up, became an adult and old at the same time.

Meanwhile the younger generation or the younger group is also often referred to, in the context of human life, are part of a community with age and strategic functions. (Kurniadi, 1987). In addition, it must be recognized that the presence of young people or youth is a national asset, but on the other hand it must be admitted also that their existence is a heavy burden to society need to think in terms of their needs such as various types of educational needs, the feasibility of life, and no less important is the field job.

The young generation in a general sense is a group of people aged 0-35 year. In sociological and practical, members or individual in the group that had the same experience, especially big events experienced simultaneously by all communities; for example, the generation of development.

By considering aspects of demographic, social, political, psychological, juridical, and human resources and in particular in support of the promotion and development of youth, the youth age range was 15 to 35 years. Study psychology for example see the youth understanding of the psychological development. The term adolescence is a concept that is inherent to the terms of the youth in this psychological perspective, which is characterized by a phase of psychological development of the search for identity.

As noted by Tilaar as quoted Kurniadi (1987) review the definition of youth or young people in pedagogical and psychological perspectives. In this perspective, young people or youth is characterized by a trait that is synonymous with rebel youth; brave but short sense, but often hit chromo dynamic, passionate but often do strange thing. Singkanya together with romantic youth. Further stated that the youth and youth is a period of development that is considered strange but interesting. When viewed from the essence of youth, then there are two basic assumptions that need attention are:

First, the appreciation of the human development process rather than as a continuum that connect but fragmentary, fragmented and each fragment has its own meaning. Youth is distinguished from the parent and child of each fragment represents a value of its own development.

Second, the key assumptions which are in addition to the assumption of -life, is the position of youth in the direction of life itself. Classical interpretations based on the assumption that the pattern of life has been somewhat limited and determined by ideas which represent the older generation hidden behind tradition.

If we look at the psychology of youth in the range of psychological development both physically and mentally, then the study of politics more emphasis on the properties of such revolutionary youth and opponents of the status quo, as well as other properties as proposed by Ferrari in its political inheritance law that is at the ready, reactionary, and thrilling. Thus, a better understanding that the political views of young people were not seen in terms of age and psychological development, but rather suppress the activity of thought and political activities. Meanwhile, in the sociological - anthropological perspective, interpreted as youth who are learning to adapt, socialize, and integrate with the community. With the learning process as it is expected to perform the function of youth role as the creator of brilliant ideas in people's lives. Finally, the economic standpoint, the youth group is represented as a man with the potential to be developed into human resources (human resources) that are reliable and quality, both in terms of physical and mentality, as well as monumental works.

Actualization of the role of young people in the development of civic engagement in the form of political participation. Participation is one of the characteristics of a good citizen. There is no reason for a citizen to not participate, because participation is mandatory for citizens, as the owner of sovereignty. In general, participation can be formulated as a growing participation or involvement of citizens in the state, governing, and society. There are three elements that must be met to be considered a citizen to participate in the activities of national, state, and governing (Wasistiono , 2003), namely : (1) there is a sense of volunteerism ( without coercion ) ; (2) no emotional involvement; and (3) to benefit directly or indirectly from involvement . 
Here are some examples of the political behavior of young people in accordance with the rules, as a manifestation of civic engagement, namely:

1) Promote the common interests of the individual or individuals.

2) Solving conflicts through peaceful means and avoid solving a violent manner.

3) Not impose the will of the other party or any other person, the excuses or reasons for personal gain

4) Exercise the rights and obligations responsibly.

5) Not doing various actions or actions that harm the public interest / public at large.

6) Criticize the government in ways or procedures or constitutional right.

7) solve the problems encountered along the way and avoiding dialogue in ways that reflect arbitrariness

\section{CONCLUSION}

In essence, Civic Engagement with regard to the rights and obligations of a citizen to carry out a wide range of general interest, determining policies kindness as something to be achieved, through the existence of institutions that will provide services to the community. Actualization of civic engagement in the political community is done through the involvement of citizens in the political life of society ( state ) in which citizens play an important role in it. The role of young people in the development of civic engagement in the context of political development, carried out through a variety of activities or active participation in various aspects of the life of society, nation and state .

Given the importance of civic engagement in the context of political development, on this occasion, the authors propose some suggestions or recommendations to the relevant parties, as follows :

1) For the government, in order to optimize in developing young people as a successor to the nation's development through intensified training activities that directly benefit perceived by the younger generation. By doing so, young people can develop civic engagement well, towards dynamic political development of the nation.

2) Young citizen of the country should have a spirit (enthusiasm) and spirit to actualize different potentials in order to participate actively in the political development of the nation poses.
3) School through Civic education teacher should be able to develop creative and innovative learning model Civic education who can develop young people ownership in this case the student in the context of people's lives, nation, and state. Learning that reflect and implement approaches such as reflective inquiry learning model portfolios, discussions, project models, and interactive learning models of other highly recommended to be applied adaptively in accordance with the conditions of the school and student characteristics.

\section{REFERENCES}

[1] Cogan, J. J and Derricot, R. 1998. Citizenship for the 21st Century : An International Perspective on Education . London : Cogan Page

[2] Saltmarsh \& Zlotkowski , 2011. Higehr Education and Democracy Essay On Service Learning and Civic Engagement . Temple University Press

[3] Korten , David . 1993. Getting to the Twenty First Century : Voluntary Action and the Global Agenda. Translation: Lilian Tejasudhana. Jakarta: Pustaka Sinar Harapan Dudley, R \& Gitelson . A. 2003. Civic Education, Civic Engagement, and Youth Development Civic. Journal of Education, Citizenship and Social Justice. (4).2009. 117-132

[4] Suseno , F.M. , 1994. Political Ethics. Jakarta : Gramedia Pustaka Utama

[5] Djahiri,A.K.1990. Value Clarification Technique (VCT) and Games . Bandung : Civic Education Laboratory

[6] Budiardjo, M. 1992. Fundamentals of Political Science. Jakarta : Gramedia Pustaka Utama.

[7] Huntington S. \& Nelson.1982. Political Participation in Developing Countries . Jakarta : Rineka

[8] Kurniadi , E.1987 . Youth Role in Political Development in Indonesia. Bandung : Angkasa.

[9] Plano, R \& Robin. 1994. Dictionary of political analysis. Translators : Edi S. Siregar. Bandung:GrafindoPersada.

[10] Rothney, and Frederickson.1977. Recognizing and Assisting Multi Potential of Youth. Publishing Co., Columbia

[11] Simandjuntak and Pasaribu.1990. Coaching and Development of the Young Generation. Bandung : Tarsito

[12] Surbakti. R 1998. Understanding Political Science. Jakarta : Gramedia Pustaka Utama 